IRA-International Journal of Management \& Social Sciences

ISSN 2455-2267; Vol.03, Issue 03 (2016)

Institute of Research Advances

http://research-advances.org/index.php/RAJMSS

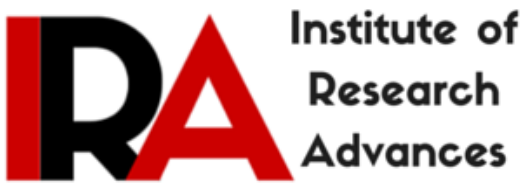

\title{
An Exploratory Study of DMIC Water Uses
}

\section{Arvind Singh}

PhD Scholar, JK Lakshmipat University, Jaipur, Rajasthan, India.

DOI: $\underline{\text { http://dx.doi.org/10.21013/jmss.v3.n3.p10 }}$

\section{How to cite this paper:}

Singh, A. (2016). An Exploratory Study of DMIC Water Uses. IRA-International

Journal of Management \& Social Sciences (ISSN 2455-2267), 3(3).

doi:http://dx.doi.org/10.21013/jmss.v3.n3.p10

\section{(C) Institute of Research Advances}

\section{(cc) EY-NC}

This works is licensed under a Creative Commons Attribution-Non Commercial 4.0 International License subject to proper citation to the publication source of the work.

Disclaimer: The scholarly papers as reviewed and published by the Institute of Research Advances (IRA) are the views and opinions of their respective authors and are not the views or opinions of the IRA. The IRA disclaims of any harm or loss caused due to the published content to any party. 


ABSTRACT
Water availability for human consumption and other uses is a priority of any welfare
government. Beside human consumption, water availability for industrial use has
become a major challenge for the governments vying for rapid industrialization for
achieving high growth rate and increasing employment opportunities. Drought prone
state like Rajasthan faces an uphill task to manage its drinking water supply in lean
years let alone providing enough water for its industries. With two third of DMIC
project running through Rajasthan, it throws major challenge before authorities to
manage water supply needed by the industries planned under DMIC. This paper
throws light on the features of DMIC project in Rajasthan. in terms of land
acquisition and demarcation by authorities, plans for water supply, management,
recycle and reuse of water, tackling infrastructure impediments related to
rehabilitation and resettlement and planning for proving a standard urban life to the
people coming to work in the DMIC industrial zones. With all the emerging trends in
Management, Science and Technology, proper water management offers not only
multifaceted opportunities but also many challenges to overcome. This paper
identifies water as one of the biggest impediments in successful development of DMIC
in Rajasthan. Though authorities have focused much on recycle and reuse of water
besides bringing in water from Chambal river, flowing 250 KM away. However, the
paper concludes that success of DMIC is going to depend on how authorities
manages water need of the industry and people in the area in coming decades and
current plans are not only too optimistic but may also result in disastrous failure of
DMIC in Rajasthan.

Key Words: Rajasthan, DMIC, Water, Management, Industries

\section{Introduction}

According to the concept paper on Delhi-Mumbai Industrial corridor (DMIC), a double lane railway track named Dedicated Freight Corridor (DFC) was envisaged by the Union government connecting Dadri Inland port near New Delhi and Jawaharlal Nehru Port in Mumbai to unleash the potential of industrial growth in India. Along with DFC a band of $150 \mathrm{~km}$ to $200 \mathrm{~km}$ on each side of the track was also chosen to be developed as DMIC. This corridor is being planned to be equipped with an array of infrastructural facilities to become a great catalyst for industrial development. It aims at developing new manufacturing cities, logistic hubs and residential townships along the DFC. It will be supported by world-class infrastructure and the objective of DMIC is to optimize on the present potential, enhance investment climate and promote the economic development of the region through creation of a long term enabling environment. It is a partnership project between India and Japan. DMIC is conceived as a Model Industrial Corridor of international standards with emphasis on expanding the manufacturing and services base and develop DMIC as the 'Global Manufacturing and Trading Hub'.

For the implementation of DMIC project requisite funds will be collected by state, central government agencies and private investors (domestic and overseas) including multi-lateral Bank such Asian Development Bank (ADB) through nodal agencies (budgetary/extra budgetary provisions) or through Viability Gap Funding/ long term soft loans extended to Special Purpose Vehicles (SPVs). The DMIC Development Corporation (DMICDC) was incorporated in January 2008 with Union Finance Minister as its chairman while the State apex body is chaired by Chief Minister of respective State (Concept Paper, 2007). 
The project goals for DMIC as mentioned in the concept note are:

- Double employment potential in five years (14.87\% CAGR)

- Triple industrial output in five years (24.57\% CAGR)

- Quadruple exports from the region in five years (31.95\% CAGR)

DMIC's Project influence states include Maharashtra, Gujrat, Rajasthan, Delhi, Haryana, Madhya Pradesh, Uttranchal, and Uttar Pradesh and Union Territories of Dadra \& Nagar Haveli and Diu \& Daman (Table 1). This covers around 14\% of the total area of India hence directly affecting approximately $17 \%$ of the total population. A total of 24 nodes have been identified under the project in which 11 investment Regions (IR) each measuring around 200 square KM and 13 Industrial Areas (IA) measuring around 100 square KM area each will be developed under the project (Concept Paper, 2007). DMIC has been envisaged to be developed in three phase over a time period of 9 years starting from 2008.

Table 1: Division of the total DMIC's Project Influence Area

\begin{tabular}{|c|c|c|}
\hline DMIC States and UTS & $\begin{array}{c}\text { Area Under Project } \\
\text { Influence Area }(\mathbf{s q ~ k m})\end{array}$ & Percentage \\
\hline Delhi & 1483 & 0.33 \\
\hline Haryana & 26410 & 6.05 \\
\hline Rajasthan & 198849 & 45.55 \\
\hline Gujrat & 120706 & 27.65 \\
\hline Maharashtra & 56760 & 13 \\
\hline UT of Dadra and Nagar Haveli & 491 & 0.11 \\
\hline UT of Daman and Diu & 122 & 0.02 \\
\hline Uttar Pradesh & 28265 & 6.47 \\
\hline Madhya Pradesh & 2866 & 0.65 \\
\hline Uttranchal & 533 & 0.12 \\
\hline $\begin{array}{c}\text { Total of All States and UTs } \\
\text { under influence }\end{array}$ & $\mathbf{4 3 6 4 8 5}$ & $\mathbf{1 0 0}$ \\
\hline
\end{tabular}

Source: Concept Paper, 2007

Figure 1: Division of the total DMIC's Project Influence Area

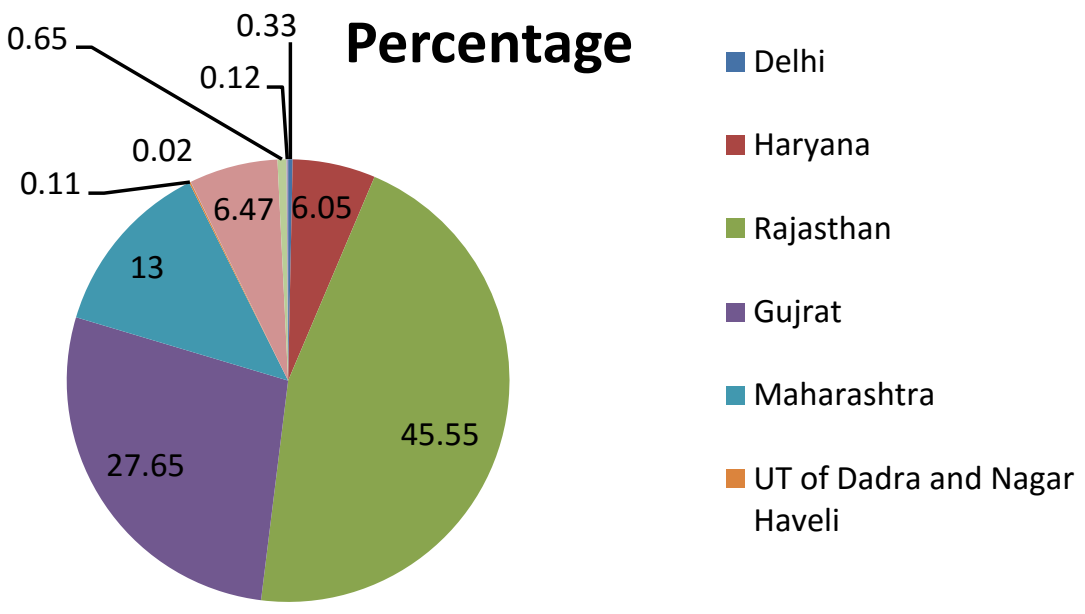


The nodes identifies in the above mentioned State are proposed to be self-sustained industrial townships with world-class infrastructure, road and rail connectivity for freight movement to and from ports and logistics hubs, aided by domestic/ international air connectivity, consistent power, quality social infrastructure and provide a internationally competitive environment favourable for setting up businesses.

According to the Census 2011, the urban population in India now stands at 377 million which has shown a growth of $2.76 \%$ per annum during 2001-11. The level of urbanization in the country has increased from $27.7 \%$ in 2001 to $31.1 \%$ in 2011. There is an increase of $3.4 \%$ during $2001-11$ which is $1.3 \%$ more than the increase in 1991-2001 which was $2.1 \%$. This increase in urbanization is one of the outcomes of the increase in the growth rate of Indian Economy. Indian Economy has shown an increase in growth rate from $6 \%$ in 1990s to $8 \%$ during the first decade of this century. This clearly reflects the power of economic growth in bringing faster urbanization during 2001-11 and vice versa (Ahluwalia, 2011).

With the projects like DMIC creating new industrial towns and rapid development, the urban population in India may sour up to 590 million by 2030 (Sankhe, et al., 2010). According to the economic and business research arm of Mckinsey Global Institute New cities in India could generate $70 \%$ of the net new jobs created by 2030, produce more than $70 \%$ of Indian GDP and drive a near fourfold increase in per capita income across the country (Amitabh, n.a.). Though across all the major quality-of-life indicators, India's cities fall well short of delivering even a basic standard of living for their residents. So, developing new cities and unleashing industrial growth potential will certainly need to be planned in such way that they not only improve the lives of people by increasing employment opportunity but also gives them a standard quality life.

The traditional industrial base of DMIC states contributes to $43 \%$ of country's GDP, more than half of industrial productions and exports and accounts for over $40 \%$ of country's factories and workers. According to the DMICDC the projected industrial CAGR for DMIC region is $13 \%$ (2010-20).

The new DMIC cities are expected to meet pressure of urbanization and also lead India's economic growth for next 20 years.

Fig: Share of DMIC states in important economic indicators

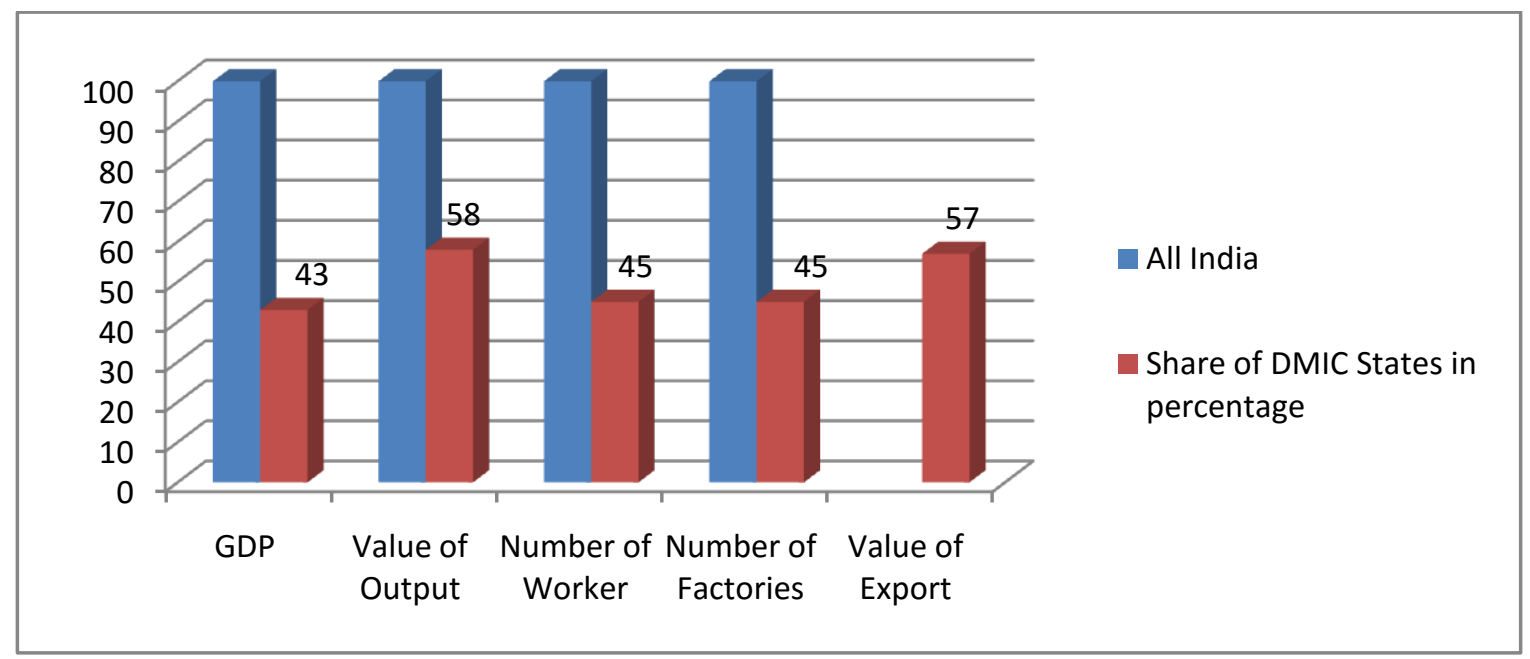

Source: Ministry of Statistics and Program Implementation (GoI), ASI and Labor Bureau 
The physical development of DMIC will be achieved in three phases and over a time frame of 9 years starting from January 2008. A time frame of five years is envisaged for Phase-1 (i.e. by December, 2012), followed by four years for Phase-2 and Phase3. Implementation of identified nodes is expected to be completed by December 2016.

In addition to the physical master planning activity, the ICT Master planning is being undertaken for the following nodes being developed in the DMIC Region at Ahmadabad Dholera Special Investment Region in Gujarat, Dighi Port Industrial Area in Maharashtra, Shendra - Bidkin Industrial Park City in Maharashtra, Khushkhera Bhiwadi Neemrana Investment Region and at Manesar Bawal Investment Region in Haryana.

The objective is to dovetail the physical master plan with the ICT Master Plan so that over a period of time, the real time control and governance of the new cities can be done by sitting in one command/ control centre.

The concepts of developing sustainable smart cities of $21^{\text {st }}$ century and interconnected roads, rail and communication system proving speed, access and world wide connectivity is inspired by successful examples such as Iskandar-Malaysia, Songdo IBD, South Korea and Sino-Singapore Tianjin City, China. The key development goals of DMIC includes Energy sufficiency through renewable sources, conservation of better agriculture land and protection of sensitive natural areas, integration of existing villages into new cities and IT-based real time control and governance of new urban areas.

\section{Objective}

The main objective of the present study is to understand the features of DMIC project in Rajasthan. in terms of land acquisition and demarcation by authorities, plans for water supply, management, recycle and reuse of water, tackling infrastructure impediments related to rehabilitation and resettlement and planning for proving a standard urban life to the people coming to work in the DMIC industrial zones.

\section{Hypothesis}

The current status of planning of water use under DMIC is not only too optimistic but may also challenge the success of DMIC in Rajasthan

\section{Rationale and Theoretical Framework}

Rajasthan with a land area of 342239 Square Km comprises $10.4 \%$ of the country's total area and around 6\% of the country's population. According to the census 2011 (GoI, 2011), Rajasthan has population of 68.62 million with population density of 201 persons per square kilometre. The climate of Rajasthan is characterized with hot and dry winds and $60 \%$ of its area falls within the Great Indian Desert of Thar. A substantial proportion of population resides in this area despite dry winds and scanty rainfall. Report on water resources (Central Ground Water Board, 2006) mentions that the state has only $1 \%$ of India's water resources

This places Rajasthan, which is also, geographically, the largest state in the country, as the most vulnerable area in the country in terms of drought and scarcity and is also most vulnerable to poverty and ecological degradation (Mundetia \& Sharma, 2014).

Rajasthan is uniquely situated to benefit the most from DMIC project as $39 \%$ of total influence areas and $25 \%$ of total DMIC population falls in the state. $71 \%$ of the 
state's areas, $84 \%$ of the total state population and 25 out of 33 districts will be directly benefiting from development of DMIC makes Rajasthan an attractive destination for future investment for setting up operational units and industries. The impact area of the project in Rajasthan is estimated to be around 165900 lakh square kilometer $(553 \mathrm{KM} * 300)$.

The project is expected to enable world class infrastructure development, attracting investment from both domestic and global investors and become catalyst for organic and planned development. 139 out of 222 towns in Rajasthan are falling under the influence zone of DMIC which includes two metro towns of Jaipur and Jodhpur and 12 other class-I towns.

The Mckinsey report says that in Rajasthan $24 \%$ of the population was living in urban areas in 2008 which could rise up to $33 \%$; an increase from 15.5 million to 29.5 million people living in the cities. Jaipur is included among 13 cities in the country which will have population more than 4 million by 2030. Report estimated population of Jaipur around 5.4 million by 2030 with GDP of $\$ 24$ billion at 2008 prices. According to 2011 census level of urbanization in Rajasthan is still under 25\%.

Khushkhera-Bhiwadi-Neemrana $(\mathrm{KBN})$ industrial region has been identified in Rajasthan under DMIC to be developed as an integrated industrial township in the first phase and Jodhpur-Pali-Marwar (JPM) has been identified as an industrial area. The other areas proposed for development under DMIC are Ajmer-Kishangarh, Rajsamand-Bhilwara and Jaipur-Dausa. Bureau of Investment promotion (BIP) is the nodal agency for DMIC project in the state and a MoU has already been signed between DMICDC and GoR on February 20, 2009. A State Level Steering Committee on DMIC had been constituted under the Chairmanship of Chief Secretary on March26, 2009.

According to the information brochure of Bureau of Investment Promotion (BIP), GoR, DMICDC appointed consultants on April19, 2010 for the preparation of developmental plans for the KBN Investment Region and undertaking technoeconomic studies for the three Early Bird Projects:

1. Project for a Knowledge City within the Shahjahanpur-Neemrana-Behrore (SNB) Global City with an area of 50-60 sq. kms to house big knowledge clusters with related support Infrastructure.

2. Aerotropolis Project

3. Central Spine Connecting Global City with Bhiwadi-Tapukara Industrial Complex via Ajarka.

A 1000 MW Gas based Power Plant has also been proposed to be set up by DMICDC in the State, a location has been identified at Banswara district for the project.

In first phase, GoR is concentrating on development of KBNIR. 
Fig: Concept plan of KBN Industrial Region

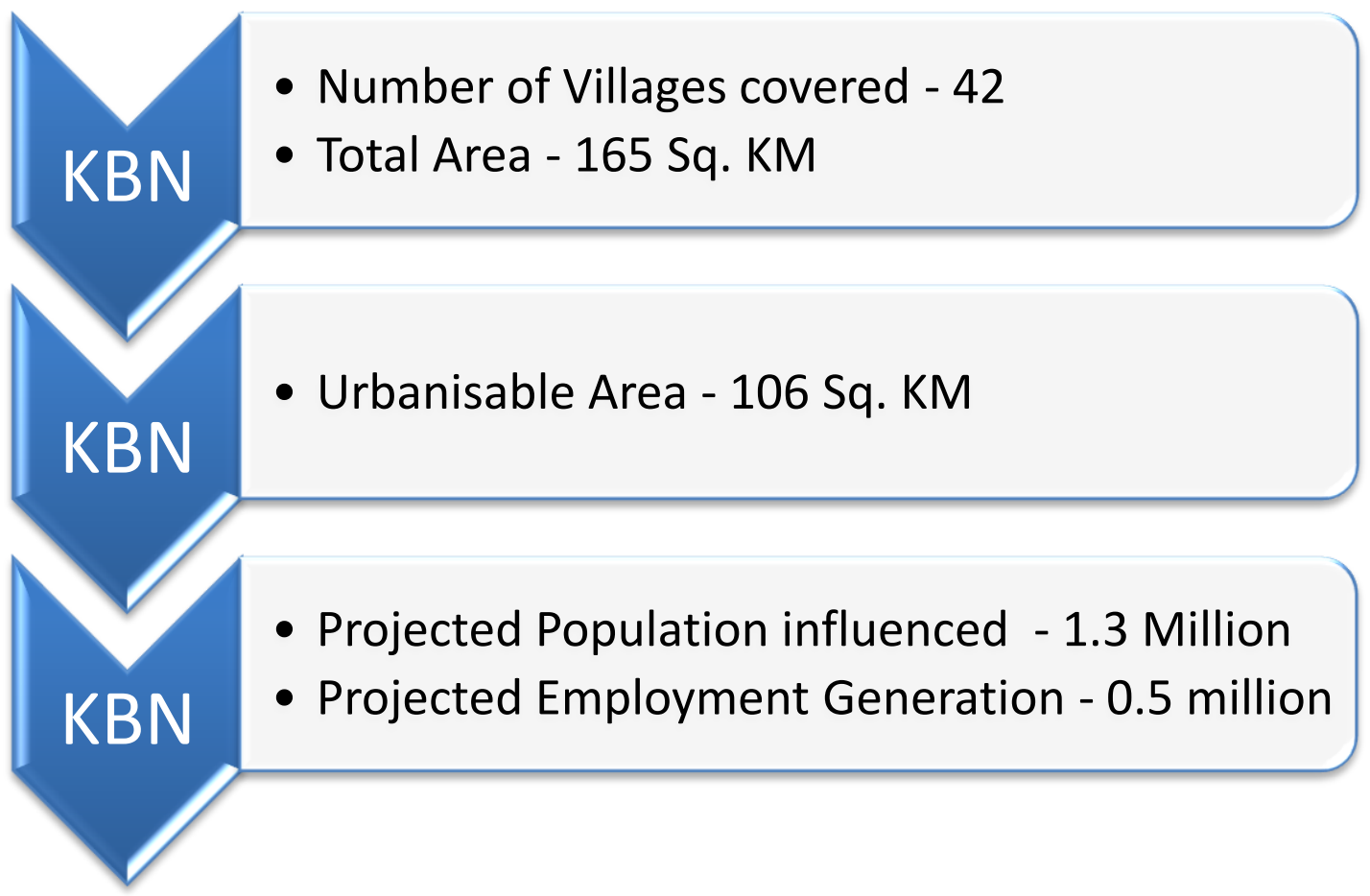

The master plan of KBN area under DMIC includes 160 square KM area with target of attracting electronic, automotive, pharmaceutical, Bio-tech and ICT industries. A green-field integrated township is proposed to be developed as a model future city spread over 160square KM which will include a knowledge city, residential infrastructure promoting neighborhood concepts for various income classes, ecological industrial parks, SEZ, IT/Bio-technology hubs.

The other projects of DMIC in Rajasthan includes 6MW solar micro grid power project in Neemrana, Smart Community Project in Neemrana and development of Mass Rapid Transit System (MRTS). New technological intervention such as Artificial Aquifer Recharge and recovery (AARR) technique, Smart Grid Technology, Smart Metering, Centralized monitoring through CCTV and access control techniques and introduction of IT in city administration, facility management and transportation services are also been planned.

The delineation of KBNIR of $162 \mathrm{Sq} \mathrm{KM}$ covering 42 villages has already been completed in January 2011. The final concept plan for KBN investment region was approved by the GoR in its steering committee meeting on June18, 2012. Based on the approval, Kuiper Compagnons BV the consultant for Rajasthan IR submitted the development plan of the region.

The state government on May26, 2013 notified the master plan for ShahjahanpurBehror-Neemrana (SBN) Urban complex 2041 which also includes master plan for KBN-IR. The State Government has also got a new Act namely Special Industrial Region (SIR) Act drafted for implementation of DMIC project in Rajasthan which is yet to be passed in state assembly. The act is intended to provide legal framework empowers the State Government and its agencies for Establishment, Operation, Regulation and Management of the SIR (s). The SIR area will be an industrial township except the village site area of a village panchayat, municipal area and municipal corporation area, within the meaning of Article 243 (q) of the Constitution of India. Regional Development Authorities (RDA) will be created as apex bodies to administer and plan for SIRs under the act. 
Jodhpur and Neemrana-Bhiwadi has been nominated by state government for smart community project. A consortium led by Sumitomo Corp. has been appointed by METI, Japan to undertake a study of Smart Community at Neemrana.

The State Government has approved five projects for conducting the pre - Feasibility Study for KBN-IR:

\section{Waste Water Conveyance System form DJB (Okhla Treatment Plant)}

2. Integrated Multimodal Passenger Hub

3. High Tech Agriculture/ Food Cluster

4. Water Management for Phase - 1

5. Public Transportation for IR.

Draft Pre - feasibility reports for all the above projects have been submitted by the consultant and are under review by DMICDC and the State Government.

The DMIC project in Rajasthan is being seen a catalyst for industrial growth and to increase the share of industrial output in the state economy which is largely based on agriculture. With the development of DMIC the share of industry and service section in state economy is expected to rise significantly. Rajasthan being situated at 'just the right place' in NCR is in position to attract large investment and the project is a giant step towards impetus for unleashing industrial sector growth in the desert state.

Rajasthan was $17^{\text {th }}$ in Human Development Index (HDI) report of 2011. This indicate low level of social development and lack of basic infrastructure of social development such as schools, hospitals, roads, drinking water and sanitation facilities particularly in rural Rajasthan where most of the population resides. Even in comparative more developed areas like Alwar where first node of DMIC region falls in the state, the state of social infrastructure is not satisfactory.

So with accelerated urbanization and industrialization planned under DMIC node area, the development of social infrastructure is going to be a challenge. Rapid industrial and population growth is expected to come with its own inherent problems such as housing, water supply, sanitation and sewage treatment etc.

Therefore, there is an urgent need to unleash social infrastructure development in DMIC node to achieve the target of future industrial growth with standard amenities and lives for those who comes to work and contribute to the future of Rajasthan.

\section{Methodology}

The present study has been done though an exploratory research using the secondary data from various resources mainly including the concept paper of DMIC and other policy papers of the Government of Rajasthan.

\section{Discussion}

\section{DMIC Impact on Water Resource and Ecology}

For Phase 1 there will be 12 nodes including six industrial areas and six investment areas. They are as follows:

Investment Regions:

- Dadri-Noida-Ghaziabad in UPas General Manufacturing Investment Region 
- Manesar-Bawal Region in Haryana as Auto Component/ Automobile Investment Region

- Khushkh

In Rajasthan the identified investment region and industrial area include:

- Kushkhera-Bhiwadi-Neemrana as Investment Region in Phase 1

- Jaipur- Dausa as Industrial Area in Phase 1

- Ajmer- Kishangarh as Investment Region in Phase 2

- Rajsamand-Bhilwara as Industrial Area in Phase 2

- Pali-Marwar as Industrial Area in Phase 2

The KBN area receives $61.60 \mathrm{CM}$ rains per annum in which $90 \%$ rains comes through south-western monsoon. The average rain varies from $30 \mathrm{CM}$ to $80 \mathrm{~cm}$ in the area but still above the state average of $53.60 \mathrm{~cm}$.

Mckinsey identifies water supply as the biggest constraint in urban areas in India and predicts that it could drop from an average of 105 liters per day per person to mere 65 liters with large section of population having no access to potable water at all.

According to report of Ground water department in 2007, in Tijara tehsil the ground water level varies from 9.70 meter to 44.65 meters. The master plan states that at few places where groundwater level was 44.65 in 2007, the well got dried in 2008 showing high rate of ground water exploitation. At RIICO industrial areas in the region water level varies from 300-400 meters as all the water requirement of industries are being met through extraction of groundwater.

There are five major operational industrial areas in Greater Bhiwadi Complex namely Bhiwadi, Chaupanki, Khuskhera, Tapookra and Sarekhurd, while there are few isolated industries along Tijrara road outside existing RIICO areas. A total number of industries in these areas are 2570 in which 1745 are already running while 825 are under construction. Development of two new industrial areas at Kaharani and Pathredi is under progress.

The total demand of water in Greater Bhiwadi Complex by 2031 is expected to be around 580MLD. The domestic waste water generated by that time is estimated at 185.9MLD while 223.4MLD industrial affluent will be produced by 2031 .

There is no perennial source of water in the KBN-IR area. Sahibi river flows in the vicinity but sustained exploitation of ground water in its bed may run into problems like over exploitation and deterioration in water quality.

The master plan suggests four potential sources of water for the region which includes -

a. tapping water from western Yamuna Canal near Bhiwani or Loharu,

b. Lower Ganga Canal in Ghaziabad,

c. treated water from Delhi Jal Board for industrial and non-drinking purposes and

d. Water from Chambal river.

As the first three proposed sources may run into complex inter-state agreements, the safest source master plan have suggested is from Chambal river situation 250KM away and would require water lifting of 150 meters. Master plan-2041 also suggests not allowing industries which consume lots of water and recycling and Re-use of water. The use of treated water from New Delhi is also proposed for KBN-IR Township. 
DMIC regions faces over exploited ground water situation and problem of salinity, salt disposal challenges and impact of climate variability as average rainfall in the region is not more than $500 \mathrm{~mm}$ per annum. Increasing water demand and changing priorities need out of the box thinking to solve the water problem.

Table- Waste Generation and Treatment in KBN (in MLD)

\begin{tabular}{|l|l|l|l|}
\hline Demand Sectors & 2011 & 2021 & 2031 \\
\hline $\begin{array}{l}\text { Total Fresh water } \\
\text { demand (Including } \\
\text { UFW) }\end{array}$ & 118 & (Phase-2) & (Phase-3) \\
\hline $\begin{array}{l}\text { Waste Water } \\
\text { Generated }\end{array}$ & 72 & 230 & 405 \\
\hline $\begin{array}{l}\text { Recycle water after } \\
\text { tertiary treatment }\end{array}$ & 65 & 139 & 250 \\
\hline $\begin{array}{l}\text { Recycle water used } \\
\text { by Industries }\end{array}$ & 59 & 125 & 225 \\
\hline $\begin{array}{l}\text { Recycle water other } \\
\text { uses }\end{array}$ & 6 & 34 & 150 \\
\hline
\end{tabular}

Source: DMICDC

The total fresh water demand of DMIC in Rajasthan at KBN is estimated to 118MLD in 2011 which will rise around four times to 405MLD in 2031. 250MLD waste water is expected to be generated after completion of phase-III of DMIC in Rajasthan but the STP planned under the project only has capacity of treating around 200MLD water. A water pumping plant is been proposed at Nangalsiya village on the banks of Sahibi river.

Table - Capacity of planned Sewage Treatment Plants in KBN

\begin{tabular}{|l|l|l|l|l|l|l|}
\hline S.N. & Description & Phase-I & Phase-II & Phase-III & $\begin{array}{l}\text { Total } \\
\text { (MLD) }\end{array}$ & $\begin{array}{l}\text { Nature of } \\
\text { Plant }\end{array}$ \\
\hline 1. & STP-1 & 46 & 12 & & 58 & CETP \\
\hline 2. & STP-2 & 1 & 22 & 14 & 37 & STP \\
\hline 3. & STP-3 & & 35 & & & STP \\
\hline 4. & STP-4 & 14 & 11 & 32 & 56 & STP \\
\hline 5. & STP-5 & & & 14 & 14 & CETP \\
\hline 6. & STP-6 & & 14 & 39 & 52 & CETP \\
\hline
\end{tabular}

Source: DMICDC

A pre-feasibility water resource study was awarded to PDCOR on February 6, 2009 for the Khuskheda- Bhiwadi-Neemrana node of DMIC; a Draft Report and the Final Report on the Study has been submitted with certain recommendations, which are not in public domain yet.

Integrated Water Resource Management Plan

A high level committee chaired by Secretary of Union Ministry of Water Resource on November 6, 2012 requested the State Governments to arrange water supply to the proposed new industrial cities in DMIC and suggested that State Governments may consider plans for the efficient use/management of water in irrigation sector where $80 \%$ of the water resources are used. DMICDC is getting an 'Integrated Water Resources Management Plan' prepared for its nodes in Haryana and Rajasthan.

Consultant is being shortlisted for preparation of an Integrated Water Resources Management Plan and DPR for alternative sources of water for the KBNIR. 


\section{Water supply and Waste Water Management in JPM-IA}

The consultant has submitted the revised report and has recommended Rajiv Gandhi lift canal as a source for potable water demand for Jodhpur - Pali -Marwar Industrial area. The State Government in the State Steering committee meeting held on 25th July, 2013 has approved for Rajiv Gandhi lift Canal as a source for potable water in JPMIA. Invalid source specified.

\section{Ecological Zones}

An Ecological Conservation Zone has been proposed on the south east of outer peripheral road covering 2250 Hectare. The area consists of ravines which is eco sensitive area needing stabilization to be protected from soil erosion and greenery for improving environmental health of the planned city of Greater Bhiwadi.

Peripheral Control Belt (PCB) has been planned between Urbanisable Area Limited and Notified Area Limits. Total area under PCB is 1375 Hectare distributed in three patches in Greater Bhiwadi Complex. ECZ falls on the south east of the outer peripheral road covering an area of 2463 hectare. The objective of PCB is to restrict haphazard development on periphery of the city along the road.

Protection of ecology and environment is the most important issue in any rapid development of industry. DMIC has planned well to ensure reuse and recycle of waste water, development of green corridor and eco-friendly cities. But strict adherence to the master plan and rules and regulations remain the biggest challenge as we have generally seen the diversions from master plan on very frequent basis.

Availability of water is also going to be a major challenge for KBN-IR DMIC node. The plan of pumping water from Chambal river situated $250 \mathrm{KM}$ away seem not feasible as in terms of cost effectiveness and also it would raise many other sensitive issues such as providing water to the areas situated along the proposed water supply line as state government has already experienced in Bisalpur Water Supply Project to Jaipur and Ajmer.

Beside this, water supply from Chambal also poses inter-state agreement; which are hard to come by as each state situated along Chambal River are already planned according to its own need ignoring the other. So, fresh water supply is going to be a challenge for survival of industries in DMIC.

\section{Conclusion}

DMIC project for Rajasthan seems to a grand plan to transform a state predominately depended on agriculture and animal husbandry to an Industrial and Manufacturing hub. The KBNIR node taken up in the first phase of the project is ideal place due to its proximity to National Capital. The industries being invited are also being carefully chosen because of limitation of water availability in the area.

State government has already issued notification under section 6 of Land Acquisition Act, so the impact of newly bought changes in land acquisition law will not affect the project at KBNIR. The works at JPM-IA are mostly related to infrastructure development which is not requiring much of the land acquisition processes to be initiated under DMIC.

The biggest challenge before success of DMIC in Rajasthan is Water Resource Management. Requirement of 400MLD water is going to be toughest task for the authorities which are planned Smart and Eco- cities in the area. Though the DMIC is stressing on reuse and recycling of water but in absence of any perennial surface 
water source it becomes difficult to comprehend the success of model being adopted for industrial development.

The only viable option stressed upon for water supply in Master Plan-2041 is lifting water from Chambal River. But issues like availability of water in National Chambal Sanctuary, cost of bringing water from a distance of $250 \mathrm{KM}$, interstate rivalry over water use in inter-state river are practical impediments for development under DMIC.

As Mckinsey reports identifies none of the Indian cities adhering to the quality of life indicators; the task of implementing concepts like Smart Cities and Eco-Cities are going to be a herculean task for DMIC to work against the odds. Infrastructure bottlenecks and impediments, non availability of proper housing, sanitation and disaster management mechanism makes the success of DMIC all more difficult.

The other challenges before DMIC may have to solve are -

- Public Funding versus PPP mode

- Monetization of Land Values

- De-politicisation of Land Values

- Technology-Life Cycle cost of Technology Vs Life

- Institutional System- Governance in New Cities

- Challenges of Water and Sewage Management

Thus, DMIC without doubt will give a great Philip to industrial development in Rajasthan but its social and environmental cost is also going to be huge for the desert state and on Sustainability Index the project may not score much.

\section{References}

Ahluwalia, M. S. (2011). Prospects and Policy Challenges in the Twelfth Plan. Economic and Political Weekly, 46(21), 88-105.

Amitabh. (n.a.). India's Urbanization Prospects. DMICDC. Retrieved July 14, 2015, from http://cseindia.org/userfiles/DMIC-amitabh.pdf

Benson, C., \& Clay, E. (1998). The impact of drought on Sub-Saharan African Economies: A preliminary Examination. Wold Bank. Retrieved October 6, 2014, from http://documents.worldbank.org/curated/en/1998/03/693685/impact-droughtsub-saharan-african-economies-preliminary-examination\#

Central Groung Water Board. (2006). Dynamic Ground Water Resources of India. Ministry of Water Resources. Faridabad: Government of India. Retrieved August 19, 2014, from http://cgwb.gov.in/documents/DGWR2004.pdf

Concept Paper. (2007). Concept Paper Delhi Mumbai Industrial Corridor. Department of Industrial Policy \& Promotion Ministry of Commerce \& Industry . New Delhi: Government of India. Retrieved September 27, 2015, from https://www.google.co.in/url?sa=t\&rct=j\&q=\&esrc=s\&source=web\&cd=1\&c $\mathrm{ad}=\mathrm{rja} \&$ uact $=8 \& \mathrm{ved}=0$ ahUKEwiv_ZjNwtjJAhVQWI4KHQEhDLsQFggbM AA\&url=http $\% 3 \mathrm{~A} \% 2 \mathrm{~F} \% 2 \mathrm{Fwww}$. dmicdc.com\%2Fdownloadfile.aspx \%3FD $\% 3 \mathrm{D} \% 2$ Fuploads\%2Ffiles\%2FUploadFile6.pdf\&usg=AFQjCNGCAXfPH VB0Btfw5dKdvKYFv

DELIVERY-MONITORING-UNIT-DMIC-Project. (2013). Status as on 31st December, 2013. Department of Industrial Policy \& Promotion. 
Greater-Bhiwadi-Master-Plan-2031. (2013). Master Plan 2031. Town Planning Department.

Master-Plan-2041. (2013). Shahjahanpur-Neemrana-Behror Master Plan . Department of Urban Development and Housing

Sankhe, S., Vittal, I., Dobbs, R., Mohan, A., Gulati, A., Ablett, J., . . Shetty, G. (2010). India's urban awakening: Building inclusive cities, sustaining economic growth. McKinsey Global Institute. Retrieved July 14, 2015, from https://www.mckinsey.com/ /media/McKinsey/dotcom/Insights\%20and\%20 pubs/MGI/Research/Urbanization/Indias\%20urban\%20awakening\%20Buildi ng\%20inclusive\%20cities/MGI_Indias_urban_awakening_full_report.ashx

State-Urbanisation-Commission. (2011). Working Group on Future Settlement patterns, Urban Forms and Urbanism (2030).

GoI. (2004). Twelfth Finance Commission Report. Finance Commission of India. Retrieved 12 22, 2014, from http://finance.rajasthan.gov.in/doc/12fcreng.pdf

GoI. (2011). Census of India. Retrieved August 18, 2014, from http://www.dataforall.org/dashboard/censusinfoindia_pca/ 